\title{
Kepemimpinan Pendidikan Di Sekolah
}

\author{
Ismail \\ ismail.izmi@gmail.com \\ Sekolah Dasar Negeri 2 Kembang kerang daya, Lombok Timur, NTB, Indonesia
}

\begin{abstract}
Abstrak
Unit satuan pendidikan merupakan salah satu organisasi yang memiliki fungsi pengorganisasian dalam satu struktur, dan tingkat struktur tertinggi adalah Kepala sekolah. Sebagai seorang pemimpin kepala sekolah harus memikul tanggung jawab keseluruhan organisasi. Selanjutnya, kepemimpinan harus dipahami lebih sebagai layanan untuk organisasi dan anggotanya. Melalui kajian literatur penelitian ini mencoba mengkaji lebih mendalam terkait kepemimpinan pendidikan di sekolah. Metode penelitian artikel ini adalah deskriptif kualitatif dimana data dalam penelitian ini dikumpulkan dengan tehnik studi dokumentasi dengan membaca, menguraikan, dan mengumpulkan berbagai artikel hasil penelitian dan kajian serta berbagai literatur yang berhubungan dengan kepemimpinan. Hasil analisis berbagai literatur, peneliti setidaknya mendapat dua kesimpulan: 1) Kepemimpinan adalah seorang yang mempunyai kemampuan, kekuatan seni untuk mempengaruhi, memberikan aspirasi, dan mengarahkan perilaku seseorang atau organisasi di dalam kerjanya dengan cara kepatuhan, kepercayaan, kehormatan, dan kerja sama yang bersemangat dalam mencapai tujuan pendidikan bersama. 2) Agar dapat mencapai tujuan pendidikan secara optimal, efektif, dan efisien, maka dibutuhkan kepemimpinan kepala sekolah yang bertanggung jawab dan memahami tugas pokok serta fungsinya. Fungsi kepemimpinan pendidikan; (1) Educator ; (2) Manager; (3) Administrator; (4) Supervisor; (5) Leader; (6) Innovator; dan (7) Motivator, disingkat EMASLIM.
\end{abstract}

Kata Kunci: Kepemimpinan, Pendidikan, dan Sekolah

\section{Pendahuluan}

Unit Satuan Pendidikan (Sekolah) merupakan institusi yang bersifat kompleks dan unik. Kompleks dikarena unit satuan pendidikan merupakan organisasi yang di dalamnya terdapat keterkaitan dari berbagai dimensi yang bertujuan untuk menuju pencapaian komitmen pendidikan. Unik karena unit satuan pendidikan didasarkan pada karakteristik tertentu yang tidak dimiliki oleh organisasi lain ${ }^{1}$. Adapun karakteristik tersebut adalah adanya proses belajar-mengajar sebagai pemberdayaan umat manusia.

Proses belajar mengajar merupakan tugas yang dilakukan untuk mencerdaskan kehidupan bangsa yang merupakan tujuan ideal untuk direalisasikan melalui sistem

\footnotetext{
${ }^{1}$ Rohmat, 'Kepemimpinan Pendidikan', Jurnal: Insania, 2006.
} 
pendidikan nasional. Dalam sistem unit satuan pendidikan, terjadi proses interaksi antara kepala sekolah, guru, pegawai, pengawas, komite sekolah serta murid. Semua proses interaksi berlangsung, karena dipengaruhi fungsi pengorganisasian, pembagian tugas, komunikasi, motivasi, kewenangan dan keteladanan.

Kompleksitas dan keunikan yang dimiliki oleh unit satuan pendidikan diatas menuntut adanya efektivitas kepemimpinan pendidikan yang sangat fundamental dalam mewujudkan pencapaian tujuan institusi pendidikan. Kepemimpinan menjadi faktor yang sangat menentukan bagi keberhasilan suatu unit satuan pendidikan. ${ }^{2}$ Walaupun banyak faktor yang turut mempengaruhi dalam keberhasilan institusi pendidikan, tetapi kepemimpinan menempati posisi yang sangat vital bagi jalannya sistem ataupun subsistem yang terdapat dalam organisasi.

Unit satuan pendidikan merupakan salah satu organisasi yang memiliki fungsi pengorganisasian dalam satu struktur, dan tingkat struktur tertinggi adalah Kepala sekolah. Kepala Sekolah berfungsi sebagai pemimpin, manajer, pendidik, pengawas, dan motivator bagi guru-guru dalam sistem pendidikan melalui pembelajaran dan latihan. Guru berinteraksi dengan sesama guru dan murid dalam kegiatan pembelajaran. Demikian pula ada pola komunikasi di dalam interaksi ini sebagai inti kegiatan kemanusiaan mengembangkan potensi anak didik menuju kedewasaan dalam makna yang luas sehingga dapat mengisi peran sesuai dengan sistem sosial ${ }^{3}$.

Untuk mencapai tujuan pendidikan sesuai dengan peran sosial sekolah, maka peran kepemimpinan pendidikan harus berjalan optimal. Secara operasional kepemimpinan pendidikan harus berlangsung efektif bagi kemajuan organisasi sekolah. Di era digital saat ini, keberhasilan dan kegagalan suatu organisasi sekolah sebagian besar ditentukan oleh mutu kepemimpinan yang dimiliki oleh seorang pemimpin dalam suatu organisasi sekolah. Untuk itu kepemimpinan pendidikan perlu diberdayakan

\footnotetext{
2 Sutarto, Dasar-dasar Kepemimpinan Administrasi (Yogyakarta: Gajah Mada University Press, 1991).

${ }^{3}$ Syafaruddin dan Asrul, Kepemimpinan Pendidikan Kontemporer (Bandung: Citapustaka Media, 2013).
} 
dengan cara meningkatkan kemampuannya secara fungsional, sehingga mampu berperan sesuai dengan tugas, wewenang, dan tujuannya.

Stephen Robbin menjelaskan", "leadership as ability to influence a group toward the achievement goals". Kepemimpinan merupakan kemampuan mempengaruhi kelompok untuk dapat mencapai tujuan sehingga kepemimpinan lebih menekankan pada sejauh mana seorang pemimpin memiliki kemampuan dalam menjadikan para bawahan dapat bersama-sama dalam mencapai tujuan yang ditentukan. Kemampuan seorang pemimpin tidak lepas dari kemampuan manajerial.

Menurut Robbins, para pemimpin membuat arah dengan cara mengembangkan visi masa depan; lalu mereka menata orang-orang dengan cara mengomunikasikan visinya dan memotivasi mereka untuk mengatasi hambatan ${ }^{5}$. Jabnoun menjelaskan, Kinerja suatu organisasi sangat dipengaruhi oleh kualitas kepemimpinannya. Pemimpin harus memikul tanggung jawab keseluruhan organisasi. Selanjutnya, kepemimpinan harus dipahami lebih sebagai layanan untuk orga-nisasi dan anggotanya ${ }^{6}$.

\section{Metode Penelitian}

Metode penelitian artikel ini adalah deskriptif kualitatif artinya mengumpulkan dan menjelaskan teori-teori yang berkaitan dengan tema di atas. Data dalam artikel ini dikumpulkan dengan tehnik studi dokumentasi dengan membaca, menguraikan, dan mengumpulkan berbagai artikel hasil penelitian dan kajian serta berbgai literatur yang berhubungan dengan tema kajian. Analisis data dilakukan melalui kegiatan menelaah dan mengkaji berbagai literatur, artikel hasil penelitian, dan artikel hasil kajian, menata, mambagi menjadi Satuan-satuan yang dapat dikelola, dan menemukan apa yang bermakna dan apa yang akan di tulis dan diputuskan untuk dilaporkan secara sistematis menjadi sebuah artikel.

\footnotetext{
4 Stephen P Robbins, Organizational Behaviour, 9thedition (Englewood Cliff, New Jersey:

Prentice-Hall inc, 2001).

${ }^{5}$ Stephen P Robbins.

${ }^{6}$ Naceur Jabnoun, Islam and Management, (Riyadh, International Islamic Publishing House, 2008).
} 


\section{Pembahasan}

\section{Pengertian Kepemimpinan}

Robbins menjelaskan7, "leadership as ability to influence a group toward the achievement goals". Kepemimpinan merupakan kemampuan mempengaruhi kelompok untuk dapat mencapai tujuan sehingga kepemimpinan lebih menekankan pada sejauh mana seorang pemimpin memiliki kemampuan dalam menjadikan para bawahan dapat bersama-sama dalam mencapai tujuan yang ditentukan. Kemampuan seorang pemimpin tidak lepas dari kemampuan manajerial.

Menurut Robbins, para pemimpin membuat arah dengan cara mengembangkan visi masa depan; lalu mereka menata orang-orang dengan cara mengomunikasikan visinya dan memotivasi mereka untuk mengatasi hambatan ${ }^{8}$. Jabnoun menjelaskan, Kinerja suatu organisasi sangat dipengaruhi oleh kualitas kepemimpinannya. Pemimpin harus memikul tanggung jawab keseluruhan organisasi. Selanjutnya, kepemimpinan harus dipahami lebih sebagai layanan untuk organisasi dan anggotanya9 . Kami mendefinisikan Ieadership sebagai kemampuan untuk mempengaruhi suatu kelompok menuju pencapaian tujuan ${ }^{10}$. Kepemimpinan adalah fenomena nyata yang penting bagi efektifitas organisasi. ${ }^{11}$

Kepemimpinan adalah kemampuan mempengaruhi perilaku orang lain dalam situasi tertentu agar bersedia bekerjasama untuk mencapai tujuan yang ditetapkan. Menurut Overton ${ }^{12}$, kepemimpinan adalah kemampuan untuk memperoleh tindakan pekerjaaan dengan penuh kepercayaan dan kerjasama. Dalam menjalankan kepemimpinannya seorang pemimpin memiliki gaya-gaya sendiri. Pendapat Overton menekankan fokus kepemimpinan terhadap kemampuan seseorang memperoleh tindakan dari orang lain. Kepemimpinan terkadang dipahami sebagai kekuatan untuk menggerakkan dan mempengaruhi orang. Kepemimpinan sebagai sebuah alat, sarana

\footnotetext{
7 Stephen P Robbins.

8 Stephen P Robbins.

${ }^{9}$ Naceur Jabnoun.

10 Stephen P Robbins

11 Gary Yulk, Leadership in Organizations, (New York, Pearson Prentice Hall, 2010).

12 Rodney Overton, Leadership Made Simple, (Singapura: Wharton Books, Pte. Ltd., 2002).
} 
atau proses untuk membujuk orang agar bersedia melakukan sesuatu secara sukarela/sukacita. Ada beberapa faktor yang dapat menggerakkan orang, yaitu karena ancaman, penghargaan, otoritas, dan bujukan ${ }^{13}$.

Kepemimpinan memiliki banyak perilaku, Yukl mengemukakan bahwa perilaku pemimpin yang didefinisikan secara luas: kepemimpinan suportif (mirip dengan pertimbangan) dan kepemimpinan direktif (serupa dengan memulai struktur dan kepemimpinan instrumental). Dua perilaku pemimpin lainnya ditambahkan dalam versi selanjutnya oleh

House dan Mitchell (1974). Keempat perilaku tersebut didefinisikan sebagai berikut14:

1. Kepemimpinan yang mendukung: Memberikan pertimbangan terhadap kebutuhan bawahan, me-nunjukkan kepedulian terhadap kesejahteraan mereka, dan mencipta kan iklim yang bersahabat di unit kerja.

2. Arahkan kepemimpinan: Membiarkan bawahan tahu apa yang diharapkan dari mereka. Untuk mela-kukan, memberikan bimbingan khusus, meminta bawahan untuk mengikuti aturan dan prosedur, dan menjadwalkan dan mengoordinasikan pekerjaan.

3. Kepemimpinan partisipatif: Berkonsultasi dengan bawahan dan mempertimbangkan pendapat dan saran mereka.

4. Pemimpin yang berorientasi pada prestasi, berpegang teguh: Menetapkan tujuan yang menantang, mencari kinerja yang lebih baik, menekankan keunggulan, dan menunjukkan keyakinan bahwa bawahan akan mencapai standar yang tinggi.

Ada enam teori kepemimpinan $\operatorname{tim}^{15}$.

1. Komitmen Tusk, Sejauh mana anggota unit berusaha untuk mencapai kinerja tingkat tinggi dan menunjukkan tingkat komitmen pribadi yang tinggi terhadap tujuan tugas unit.

\footnotetext{
${ }^{13}$ Veithzal Rivai, Kepemimpinan dan Perilaku Organisasi (Jakarta: Rajawali Press, 2003)

${ }^{14}$ Gary Yukl.

${ }^{15}$ Gary Yukl.
} 
2. Kemampuan dan kejelasan peran. Sejauh mana anggota unit memahami tanggung jawab pekerjaan individu mereka, tahu apa yang harus dilakukan, dan memiliki keterampilan untuk melakukannya.

3. Organisasi dari uork. Sejauh mana strategi kinerja yang efektif digunakan untuk mencapai tujuan tugas unit dan pekerjaan diatur untuk memastikan pemanfaatan personel, peralatan, dan fasilitas secara efisien.

4. Kerja sama dan rasa saling percaya. Sejauh mana anggota kelompok saling percaya, berbagi informasi dan ide, saling membantu, dan mengidentifikasi dengan unit kerja.

5. Sumber daya dan dukungan. Sejauh mana kelompok memiliki dana anggaran, peralatan, perlengkapan, persediaan, personel, dan fasilitas yang diperlukan untuk melakukan pekerjaan, dan informasi atau bantuan yang diperlukan dari unit lain.

6. Koordinasi eksternal. Sejauh mana kegiatan unit kerja disinkronkan dengan kegiatan yang saling tergantung di bagian lain dari organisasi dan organisasi lain (mis.,

Pemasok, klien, mitra usaha patungan).

Berdasarkan pendapat-pendapat di atas dapat disimpulkan bahwa kepemimpinan adalah seorang yang mempunyai kemampuan, kekuatan seni untuk memengaruhi, memberikan aspirasi, dan mengarahkan perilaku seseorang atau kelompok/organisasi (memotivasi individu tanpa adanya unsur paksaan) di dalam kerjanya dengan cara kepatuhan, kepercayaan, kehormatan, dan kerja sama yang bersemangat dalam mencapai tujuan bersama.

\section{Unsur-unsur Kepemimipnan}

Kepemimpinan ${ }^{16}$ berlangsung di dalam sebuah organisasi yang dalam arti statis merupakan wadah dalam bentuk suatu struktur organisasi. Di dalam struktur itu terdapat unit-unit kerja sebagai hasil kegiatan pengorganisasian berupa pembidangan dan pembagian pekerjaan (tugas-tugas) sejenis atau serumpun ke dalam satu unit kerja.

Ada lima unsur dalam proses kepemimpinan yaitu: 1) pemimpin merupakan orang yang mengarahkan pengikut, melahirkan kinerja/aktivitas, 2) pengikut merupakan orang yang bekerja dibawah pengaruh pimpinan, 3) konteks adalah situasi

\footnotetext{
${ }^{16}$ Abdul Aziz Wahab, Anatomi Organisasi dan Kepemimpinan Pendidikan (Bandung: Alfabeta, 2008)
} 
(formal atau tidak formal, social atau kerja, dinamis atau statis, darurat atau rutin, rumit atau sederhana sesuai hubungan pemimpin dan pengikut), (4) proses merupakan tindakan kepemimpinan, perpaduan memimpin, mengikuti, bimbingan menuju pencapaian tujuan, pertukaran, membangun hubungan dan (5) hasil adalah yang muncul dari hubungan pemimpin, pengikut dan situasi (rasa hormat, kepuasan dan kualitas produk. ${ }^{17}$

Ada tujuh unsur atau komponen dalam kepemimpinan, yaitu18:

a. Adanya pemimpin dan orang lain yang dipimpin atau pengikutnya;

b. Adanya upaya atau proses mempengaruhi dari pemimpin kepada orang lain melalui berbagai kekuatan;

c. Adanya tujuan akhir yang ingin dicapai bersama dengan adanya kepemimpinan itu;

d. Kepemimpinan bisa timbul dalam suatu organisasi atau tanpa adanya organisasi tertentu;

e. Pemimpin dapat diangkat secara formal atau dipilih oleh pengikutnya;

f. Kepemimpinan berada dalam situasi tertentu baik situasi pengikut maupun lingkungan eksternal;

g. Kepemimpinan Islam merupakan kegiatan menuntun, membimbing, memandu, dan menunjukkan jalan yang diridhai Allah.

Pendapat lain mengemukakan, ada dua hal penting dalam kepemimpinan, yaitu ${ }^{19}$ :

a. Kepemimpinan adalah suatu kelompok fungsi, yang terjadi tidak hanya dalam proses dua orang atau lebih yang berinteraksi;

b. Pemimpin dimaksudkan berusaha untuk mempengaruhi perilaku dari orang-orang lain. Pemimpin dalam organisasi adalah orang yang diserahi tugas dan tanggung jawab untuk memimpin organisasi. Pemimpin memiliki kemampuan merancang strategi dan mengkoordinasikan sumber daya dengan bersikap kooperatif untuk memperlancar pekerjaan dalam mencapai tujuan.

\footnotetext{
17 Syafaruddin dan Asrul.

18 Veithzal Rivai.

19 Robert G. Owens, Organizational Behaviour in Education, (Boston: Allyn and Bacon, 1995).
} 


\section{Peran Kepemimpinan}

Peran adalah seperangkat pola perilaku yang diharapkan berkaitan dengan tugas seseorang dalam kedudukan pada suatu unit sosial. Peran dapat juga diartikan sebagai perilaku yang diatur dan diharapkan dari orang dalam posisi tertentu. Pemimpin di dalam organisasi mempunyai peranan, setiap pekerjaan membawa serta harapan bagaimana penanggung peran berperilaku. Fakta bahwa organisasi mengidentifikasi pekerjaan yang harus dilakukan dan perilaku peran yang diinginkan yang berjalan dengan seiring pekerjaan tersebut, juga mengandung arti bahwa harapan mengenai peran penting dalam perilaku bawahan ${ }^{20}$.

Newell21 peran adalah sama dengan perilaku dalam kedudukan tertentu dan mencakup perilaku itu sendiri dan sikap serta nilai yang melekat dalam perilaku. Peran adalah harapan-harapan yang merupakan ketentuan-ketentuan tentang perilaku atau aktivitas yang harus dilakukan seseorang dalam kedudukan tententu, dan perilaku aktual yang dijalankannya pada organisasi atau masyarakat. Ada kaitan antara peran dengan perilaku. Peran menuntut adanya aktivitas atau perilaku yang sesuai dengan yang diharapkan. Intinya adalah dalam setiap kedudukan ada peran yang dimainkan dengan terungkap melalui berbagai perilaku yang ditampilkan ${ }^{22}$.

Peran kepemimpinan dapat diartikan sebagai seperangkat perilaku yang diharapkan dilakukan oleh seseorang sesuai dengan kedudukannya sebagai pemimpin. Dalam aplikasinya, peran kepemimpinan yang dicontohkan oleh Nabi Muhammad SAW dapat dibagi menjadi dua bagian, yaitu:

a. Servan (pelayan). Memberikan pelayanan pada anak buahnya untuk mencari kebaha giaan dan membimbing mereka menuju kebaikan;

b. Guardian (penjaga). Menjaga komunitas Islam dari tirani dan tekanan. Seperti diungkapkan pada Sahih Muslim No. 4542, yaitu: “pemimpin bagi muslim adalah perisai bagi mereka"23.

${ }^{20}$ Veithzal Rivai.

${ }^{21}$ Wahyudin Nur Nasution, 'Kepemimpinan Pendidikan di Sekolah', Jurnal Tarbiyah, (2015)

22 Syafaruddin dan Asrul.

${ }^{23}$ Veithzal Rivai. 
Menurut Nanus24, ada empat peran kepemimpinan efektif, yaitu sebagai penentu arah, agen perubahan, juru bicara dan pelatih. 1), penentu arah artinya pimpinan harus mengembangkan visi dan membagi semua orang untuk mewujudkannya. 2), agen perubahan, artinya untuk memerankan sebagai agen perubahan, pemimpin harus mampu mengantisipasi perkembangan dunia luar, menilai implikasi untuk pelaksanaan dan permbedayaan orang menuju perubahan. 3), juru bicara, artinya pemimpin harus mampu bernegoisasi dengan organisasi lain, membangun jaringan kerja, memberikan gagasan sumber daya atau informasi bagi organisasi. 4), pelatih, artinya pemimpin harus memberdayakan staf dan pegawai agar bersemangat mengejar visi. Sebagai pelatih pemimpin juga menjadi teladan dalam usaha mewujudkan visi menjadi kenyataan.

\section{Konsep Kepemimpinan Pendidikan}

\section{Pengertian Kepemimpinan Pendidikan}

Makawimbang dalam bukunya menjelaskan bahwa kepemimpinan pendidikan merupakan kemampuan untuk menggerakkan pelaksanaan pendidikan, sehingga tujuan pendidikan yang telah ditetapkan dapat dicapai secara efektif dan efisien ${ }^{25}$. Soetopo dan Soemanto (1982)26 menjelaskan bahwa kepemimpinan pendidikan adalah kemampuan untuk mempengaruhi dan menggerakkan orang lain untuk mencapai tujuan pendidikan secara bebas dan sukarela.

Fenomena kepemimpinan organissasi pendidikan dan administrasi adalah terkait dengan kepemimpinan yang diterapkan dalam kegiatan orang dalam kedudukan sebagai pengambil keputusan dalam berbagai jenjang organisasi pendidikan informal yang berinteraksi dengan organisasi formal. Adapun orang-orang yang terlibat dalam masalah itu adalah pengawas pendidikan, kepala sekolah, direktur akademi, rektor perguruan tinggi, pimpinan dalam organisasi guru, pimpinan dalam organisasi orang tua dan guru dan pimpinan

\footnotetext{
24 Syafaruddin dan Asrul.

25 Jery H. Makawimbang, Kepemimpinan Pendidikan yang Bermutu (Bandung: Alfa Beta, 2012)

26 Wahyudin Nur Nasution.
} 
organisasi formal, Morphet dkk (1982) ${ }^{27}$.

Kepemimpinan pendidikan merupakan sebagai suatu kemampuan dan proses mempengaruhi, mengkoordinir dan menggerakkan orang-orang lain yang ada hubungannya dengan pengembangan ilmu pendidikan dan pelaksanaan pendidikan dan pengajaran agar tercapai tujuan secara efektif dan efisien ${ }^{28}$.

Kepemimpinan pendidikan yang dijalankan oleh kepala sekolah atau pempinan lembaga pendidikan lainnya mengandung beberapa unsur yaitu ${ }^{29}$ :

a) Proses mempengaruhi para guru, pegawai, dan murid-murid serta pihak terkait (komite sekolah dan orang tua siswa);

b) Pengaruh yang dimaksudkan agar orang lain melakukan tindakan yang diinginkan;

c) Berlangsung dalam organisasi sekolah untuk mengelola aktivitas pembelajaran;

d) Kepala sekolah diangkat secara formal oleh pejabat kependidikan atau yayasan bidang pendidikan;

e) Tujuan yang akan dicapai melalui proses kepemimpinannya yaitu tercapainya tujuan pendidikan lulusan berkepribadian baik dan berkualitas;

f) Aktivitas kepemimpinan banyak orientasi hubungan manusia daripada mengatur sumber daya material.

Kepemimpinan pendidikan adalah kemampuan untuk mempengaruhi, mengkoordinir, dan menggerakkan orang-orang lain yang ada hubungannya dengan pelaksanaan dan pengembangan pendidikan agar dapat dicapai tujuan pendidikan/sekolah secara efektif dan efisien ${ }^{30}$.

\section{Fungsi Kepemimpinan Pendidikan}

Kepemimpinan pendidikan mempunyai fungsi: 1), kepemimpinan pendidikan sebagai manajer, 2), sebagai pemimpin, dan 3), sebagai pendidik ${ }^{31}$. Secara detail Departemen Pendidikan Nasional (Depdiknas) menyusun tujuh fungsi kepemimpinan

27 Wahyudin Nur Nasution.

28 Dirawat, dkk, Pengantar Kepemimpinan Pendidikan. (Surabaya: Usaha Nasional,1986)

${ }^{29}$ Syafaruddin, Kepemimpinan Pendidikan, (Jakarta: Quantum Teaching, 2010),

30 Pendapat dari beberapa ahli di atas yang dapat disimpulkan oleh penulis

${ }^{31}$ Wahjosumidjo, Kepemimpinan Kepala Sekolah: Tinjauan Teoretis dan Permasalahannya (Jakarta: Raja Grafindo Persada, 2002). 
pendidikan $\left.{ }^{32} ; 1\right)$, sebagai pendidik (educator); 2), manajer; 3), administrator; 4), supervisor (penyelia); 5), leader (pemimpin); (6) inovator; dan (7) motivator, yang di-singkat menjadi EMASLIM.

Sementara itu, fungsi kemampuan kepemimpinan pendidikan sebagai manajer mencakup aspek-aspek; kemampuan menyusun program, menyusun organisasi kepegawaian dalam institusi pendidikan, menggerakkan staf, dan aspek kemampuan mengoptimalkan daya institusi pendidikan.

Fungsi kepemimpinan pendidikan sebagai administrator mencakup kemampuan mengelola administrasi kegiatan belajar-mengajar serta bimbingan dan konseling, kesiswaan, ketenagaan, keuangan, sarana dan prasarana, maupun aspek kemampuan mengelola administrasi persuratan.

Fungsi kepemimpinan pendidikan EMASLIM dapat rangkum menjadi tiga unsur pokok sebagai berikut:

1) Kepemimpinan pendidikan sebagai manajer mencakup di dalamnya fungsi sebagai administrator, dan supervisor (penyelia).

2) Kepemimpinan pendidikan sebagai pemimpin (leader) mencakup di dalamnya fungsi sebagai inovator dan motivator.

3) Kepemimpinan pendidikan sebagai pendidik (educator). Adapun fungsi kepemimpinan pendidikan sebagai manajer, pemimpin dan pendidik dapat diterangkan sebagai berikut.

\section{Kepemimpinan Pendidikan sebagai Manajer}

Fungsi kepemimpinan pendidikan sebagai manajer menduduki fungsi-fungsi manajemen. Fungsi kepemimpinan pendidikan sebagai manajer identik dengan keharusan menjalankan berbagai fungsi yang ada pada manajemen. Manajer sudah pasti melakukan berbagai aktivitas, sedangkan aktivitas kerja manajer sering dikategorisasikan menjadi fungsi-fungsi manajemen.

\footnotetext{
32 Depdiknas Dirjen Pendidikan Dasar dan Menengah, Rambu-rambu Penilaian Kinerja Institusi Pendidikan (SLTP dan SMU) (Jakarta: Rineka Cipta, 2000).
} 
Fungsi manajemen menurut Leslie W. Rue dan Lloyd L. Byars adalah sebagai berikut ${ }^{33}$.

1. Planning; deciding what objectives to pursue during a future period and what to do to achieve those objectives.

2. Organizing; grouping activities, assigning activities, and providing the a thority necessary to carry out the activities.

3. Staffing; determining human resource needs and recruiting, selecting, training, and developing human resources.

4. Leading; directing and channeling human behavior toward the acco plishment of objectives.

5. Controlling; measuring performance against objectives, determining the causes of deviations, and taking corrective action where necessary.

Leslie dan Lioyd memandang fungsi manajemen yang harus dilakukan oleh manajer ada lima aspek, yaitu; 1), planning (perencanaan), meliputi penentuan tujuan organisasi untuk melaksanakan, dan penentuan berbagai hal atau strategi yang dilakukan untuk mencapai tujuan; 2), organizing (pengorganisasian), terdiri dari pengelompokan aktivitas, penentuan aktivitas, dan adanya otoritas yang akan membawa pada aktivitas pencapaian tujuan; 3), staffing (penyusunan personalia), mencakup penentuan kebutuhan sumber daya manusia, rekruitmen, seleksi, latihan, dan pengembangan sumber daya manusia; 4), leading (pengarahan) merupakan pengaturan dan penyaluran sumber daya manusia mencapai prestasi yang jadi tujuan; 5), controlling (pengawasan) mencakup pengukuran kinerja terhadap tujuan-tujuan yang telah ditentukan, penentuan kasus-kasus penyimpangan dan pengambilan tindakan untuk perbaikan yang diperlukan. Senada dengan Leslie, fungsi-fungsi manajemen menurut Henry Fayol seperti yang dikutip Hani Handoko ${ }^{34}$ menyebutkan bahwa fungsi manajemen ada lima aspek, yaitu perencanaan, pengorganisasian, penyusunan personalia, pengarahan, dan pengawasan.

\footnotetext{
${ }^{33}$ Leslie W. Rue \& Lioyd L. Byars, Management: Skills and Application(San Francisco: McGrawHill, 2000).

34 Rohmat.
} 
1. Perencanaan, meliputi pemilihan atau penetapan tujuan-tujuan organisasi, penentuan strategi, kebijaksanaan, proyek, program, prosedur, metode, sistem, anggaran, dan standar yang dibutuhkan untuk mencapai tujuan.

2. Pengorganisasian, antara lain penentuan dan sumber daya dan kegiatan kegiatan yang dibutuhkan untuk mencapai tujuan organisasi, perencana dan pengembangan suatu organisasi atau kelompok yang akan dapat "membawa" ke arah tujuan, penugasan dan tanggungjawab tertentu, pendelegasian wewenang yang diperlukan kepada individu-individu untuk melaksanakan tugasnya.

3. Penyusunan personalia adalah penarikan (recruitment), latihan pengembangan, serta penempatan dan pemberian orientasi para karyawan dalam lingkungan kerja yang menguntungkan dan produktif.

4. Pengarahan berfungsi untuk membuat atau mendapatkan para karyawan melakukan apa yang diinginkan dan harus mereka lakukan. Fungsi leading (pengarahan) sering disebut dengan leading, directing, motivating, actuating.

Jabnoun menjelaskan model manajemen Islam yang diusulkan berpusat pada nilai-nilai yang berasal dari Tauhid dan kebebasan dari tirani.Semua praktik perencanaan strategis, pengambilan keputusan, HRM (Human Resource Management), kepemimpinan dan sistem serta struktur dipilih berdasarkan sejauh mana mereka melayani nilai-nilai Islam.Semua praktik manajemen yang mendukung nilai-nilai Islam dapat dan harus dimasukkan dalam model ini khususnya dalam sistem dan struktur. Umat Islam tidak menghindar untuk belajar dari sumber apa pun ${ }^{35}$.

Nabi Muhammad (saw) berkata:"Kebijaksanaan harus dicari oleh setiap Muslim, di mana pun dia temukan, dia paling pantas mendapatkannya." (Ibn Mājah)

Sesuai fungsinya sebagai manajer, kepemimpinan pendidikan dituntut untuk mencapai tujuan akhir yang bersifat khusus (specific end). Sedangkan, kerja kepemimpinan pendidikan merupakan kerja tim yang dibantu oleh tenaga pendidik dan staf administrasi sehingga kepemimpinan pendidikan dituntut mampu

\footnotetext{
${ }^{35}$ Naceur Jabnoun.
} 
meningkatkan kinerja semua subsistem yang terdapat dalam institusi pendidikan. Hal itu semua menuntut kemampuan kepe

mimpinan pendidikan sebagai manajer untuk dapat menjalankan fungsi-fungsi manajerial.

Kepemimpinan pendidikan sebagai manajer harus dapat melakukan fungsifungsi manajemen untuk dapat merealisasikan tujuan institusi pendidikan pada pencapaian prestasi. Kepemimpinan pendidikan sebagai manajer harus melakukan fungsi-fungsi manajemen sebagai berikut:

1. Perencanaan; mencakup aspek: ( kemampuan menentukan tujuan organisasi; kemampuan merumuskan program institusi pendidikan, kemampuan menyusun strategi pengembangan; dan kemampuan menentukan standarisasi pencapaian tujuan).

2. Organizing (pengorganisasian), mencakup aspek-aspek: ( kemampuan menghimpun dan mengkoordinasi SDM; (kemampuan menghimpun dan mengkoordinasi sumbersumber material institusi pendidikan; kemampuan menentukan sumber daya yang dibutuhkan institusi pendidikan; kemampuan menentukan kegiatan yang dibutuhkan untuk mencapai tujuan; kemampuan mengembangkan organisasi atau institusi pendidikan; kemampuan penugasan dan tanggungjawab kepada tenaga pendidik dan staf administrasi).

3. Staffing (penyusunan personalia), mencakup aspek kemampuan penentuan kebtuhan SDM;( kemampuan mengadakan rekruitment; kemampuan mengadakan sampai selesai; kemampuan mengadakan pelatihan dan pengembangan SDM; kemampuan mengadakan orientasi pada tenaga pendidik dan staf administrasi).

4. Leading (pengarahan), (mencakup aspek-aspek kemampuan menyusun job dscription; kemampuan untuk menempatkan para bawahan pada SDM yang tepat; kemampuan untuk membangkitkan semangat kerja;- kemampuan untuk memberikan arahan bagi para tenaga pendidik dan staf administrasi).

5. Controlling (pengawasan), mencakup aspek-aspek:(( kemampuan untuk penilaian kinerja bawahan; kemampuan untuk mengidentifikasi kasus-kasus penyimpangan, 
kemampuan mengadakan strategi untuk mengadakan perubahan; kemampuan menyusun strategi untuk kontrol terhadap proses pencapaian tujuan).

\section{Kepemimpinan Pendidikan Sebagai Pemimpin}

Antara manajemen dan kepemimpinan, Menurut Kotter dibedakan atas proses dan outcomes yang dihasilkan, lebih lanjut dijelaskan. Management seeks to produce predictability and order by (1) setting operasional goals, establishing action plans with time tables, and allocating resources, (2) organizing and staffing (establishing structure, assigning people to job), and (3) monitoring results and solving problem. Leadership seeks to produce organizational change by (1) developing vision of the future and strategies for making necessary changes, (2) communicating and explaining the vision, and 3) motivating and inspiring people to attain the vision. ${ }^{36}$

Seorang pemimpin harus memiliki karakteristik untuk menunjang pencapaian visi dan misi organisasi. Karakteristik pemimpin menurut Gary Yukl memiliki tujuh aspek, 37 characteristic of the leader; (1) traits (motives, personality, values), (2) confident and optimism; (3) skills and expertise; (4) behavior; (5) integrity and ethic; (6) influence tactic; dan (7) attribution about followers.

Yukl ${ }^{38}$ menyebut karakteristik pemimpin terdiri dari sifat (prayojana, kepribadian, nilai-nilai), kepercayaan diri dan optimisme, keterampilan dan keahlian, perilaku, kejujuran, dan tata susila, taktik-taktik pengaruh kebijakan terhadap pengikut. Yukl juga menyebutkan kepemimpinan dapat dikonseptualisasikan menjadi empat dimensi, yaitu (1) an intra individual process, (2) a dyadic process, (3) a group process, or (4) an organizational process.

Konseptualisasi kepemimpinan menjadi proses-proses intra-individual, pros es-proses diadik, proses-proses kelompok, proses-proses organisasi. Kepemimpinan tidak lepas dari aktivitas-aktivitas diantara intra individual, diadik, kelompok, maupun di dalam organisasi untuk mencapai komitmen bersama dalam mencapai tujuan.

Yukl juga menyebutkan taksonomi keahlian kepemimpinan ${ }^{39}$ :

\footnotetext{
${ }^{36}$ Gary Yukl.

${ }^{37}$ Gary Yukl.

38 Gary Yukl.

${ }^{39}$ Gary Yukl.
} 
(there category taxonomy of leadership skills). 1). Technical Skill, knowledge about methods, processes procedures, and techniques for conducting a specialized activity, and ability to use tools and equipment relevant to that activity. 2). Interpersonal skills, knowledge about human behavior and interpersonal processes, ability to understand the feeling, attitudes, and motives of others from what they say and do (emphasy, social sensitivity) ability to communicate clearly and effectively (speech fluency, persuasiveness) and ability to establish effective and cooperative relationships, (fact, diplomacy, listening skills, knowledge about acceptable social behavior). 3). Conceptual skill, general analytical ability, logical thinking, proficiency in concept formalism and conceptualization of complex and ambiguous relationships: creativity in idea generation and problem solving, and ability to analyze events and perceive trend, anticipate changes, and recognize opportunities and potential problem (instructive and deductive reasoning).

Yukl mengkategorikan kepemimpinan setidaknya memiliki tiga kemampuan ${ }^{40}$, yaitu (1) kemampuan teknik, (2) kemampuan interpersonal, dan (3) keahlian konseptual. 1). Kemampuan teknik merupakan ilmu pengetahuan tentang metode-metode. prosedur-prosedur proses, dan teknik memimpin khususnya aktivitas dan kemampuan penggunaan sarana prasarana yang relevan untuk aktivitas yang ada. 2). Keahlian interpersonal merupakan pengetahuan tentang perilaku manusia dan proses-proses interpersonal, seperti kemampuan untuk mengerti perasaan, sikap, motivasi dari apa yang ditetapkan dikerjakan (empati, sensitivitas sosial). Kemampuan untuk berkomunikasi secara jelas dan efektif (fasih berbicara meyakinkan) dan kemampuan untuk mengefektivitaskan dan mengadakan hubungan kooperatif. 3). Keahlian konseptual merupakan kemampuan analisis general, melogikakan pemikiran, dan kecakapan dalam menformulasi konsep dan konseptualisasi yang kompleks serta menghubungkan keduanya. Kreatif dalam membangkitkan ide dan pemecahan masalah serta kemampuan untuk menganalisis kejadian, perubahan-perubahan, antisipatif dan menghargai kesempatan, dan kemampuan menangani masalah potensial (induktif dan tanggapan deduktif).

Pemimpin lebih dituntut untuk memiliki beberapa kemampuan dalam mewujudkan beberapa visi yang telah ditetapkan serta membangun hubungan kinerja

${ }^{40}$ Gary Yukl. 
dengan para pengikut atau bawahan. Di beberapa organisasi nonprofit (seperti institusi pendidikan dan organisasi sosial) pemimpin memiliki beberapa tugas ataupun peran. ${ }^{41}$

\section{Kepemimpinan Sebagai Pendidik}

Proses pendidikan di samping secara khusus (especially) dilaksanakan di institusi pendidikan, tetapi dapat diselenggarakan di luar institusi pendidikan, yaitu melalui keluarga dan masyarakat. Bahkan, diantara para pakar berpendapat bahwa pendidikan secara klasik merupakan usaha sistematik untuk mengalihkan pengetahuan seseorang kepada orang lain. Kepemimpinan pendidikan di samping menempati fungsi yang lain, dituntut untuk dapat melaksanakan fungsinya sebagai seorang pendidik.

Jabnoun berpendapat bahwa kepemimpinan pendidikan sebagai seorang pendidik harus dapat mentransfer nilai-nilai sebagai berikut: Tauhid dan Bebas dari Tirani, Kelembaban, Tawakal, Menjauhkan dari yang haram, Fleksibilitas, Keadilan, Peduli dan Berbagi, Kerja sama, Kepercayaan, Penghematan Biaya, Efisiensi waktu, Kualitas/Ketekunan, Orientasi jangka panjang, Kesatuan tujuan, Discipliner (Pendisiplinan), Manajemen Partisipatif, Keinginan untuk belajar dan berbagi Pengetahuan. ${ }^{42}$

\section{Kepemimpinan Kepala Sekolah}

Kepala sekolah merupakan pimpinan pendidikan. Dalam kedudukannya sebagai pimpinan pendidikan yang resmi, kepala sekolah diangkat dan ditetapkan secara resmi sehingga dia bertanggung jawab dalam pengelolaan pengajaran, ketenagaan, kesiswaan, gedung dan halaman (sarana dan prasarana), keuangan, serta hubungan lembaga pendidikan dan masyarakat, di samping tugasnya dalam supervisi pendidikan dan pengajaran.

Prinsip kerja sekolah sebagai organisasi, Roe dan Drake menjelaskan ${ }^{43}$ yaitu:

a). Sekolah tidak dapat mencapai efektivitas dengan pembatasan pemahaman atas fungsinya. Rendahnya tingkat kepercyaan dan pengertian masyarakat akan membatasi

\footnotetext{
41 Stephen P. Robbins.

42 Naceur Jabnoun.

43 W.H. T. Roe dan Drake, The Principalship, (New York: Macmilalan Publishing, 1980)
} 
efektivitas sekolah; b). Pentingnya tuntutan pendidikan yang membuatnya dilindungi dan sanggahan oleh berbagai pihak partisan politik; c). Proses pendidikan yang rumit hanya akan dapat dilaksanakan melalui sejumlah lembaga, perwakilan dan aktivitas kerjasama, koordinasi dan keterpaduan pendiidikan dan lembaga sosial adalah aktivitas penting dari suatu sekolah; d). Organisasi yang efektif akan menekankan dan menggunakan secara tetap dalam keseimbangan yang lebih baik dan elemen anggota dan aktivitas administrative; e). Setiap pribadi dipengaruhi oleh kebijakan, termasuk yang di luar struktur organisasi, harus menjadi bagian yang mengamankan kebijakan. Tingkatan tindakan demokratis pada waktu tertentu bergantung atas kompetensi dan kesadaran dari keterlibatan individu; f). Tujuan administrasi sekolah adalah membantu pembelajaran dan proses pengajaran. Personil administratif harus memberikan kepemimpinan dalam peningkatan mutu pembelajaran dan harus memperhatikan anggota, staf yang memerlukan waktu, kecukupan material dan kondisi kerjasama yang lebih baik bagi kinerja dan fungsi mereka; g). Untuk mencapai keunggulan anggota staf harus memberikan kepada mereka untuk dapat memanfaatkan peluang bagi kontribusi yang signifikan secara lokal, institusional, dan penuh tujuan. Kemajuan sekolah akan diukur dari kelancaran pekerjaan, kinerja personil baik sebagai individu maupun kerjasama kelompok; h). Organisasi sekolah harus memiliki fleksibilitas yang cukup dan kemampuan adaptasi untuk menangani pengembangan keperluan baru struktur sekolah, kebijakan dan program harus menjadi bahan yang terus dievaluasi; i). Tujuan utama dari sekolah adalah membantu mencapai keuntungan budaya saat ini dan penguasaan pengetahuan yang ada. Sekolah juga betanggung jawab untuk mengembangkan kepemimpinan dalam semua peningkatan kualitas dari masyarakat; j). Tujuan dan sasaran organisasi sekolah harus dikembangkan secara bersama oleh anggota dan organisasi dan pengembangan proses bagi satu periode tertentu untuk ditinjau ulang dan direvisi menjadi tanggungjawab semua anggota personil sekolah; k). Organisasi sekolah harus jaringan akses yang mudah merupakan dalam, komunikasi dan umpan balik kepada setiap bagian dari organisasi secara formal dan kepada pusat administrasi sekolah. 
Kepemimpinan kepala sekolah adalah cara atau usaha kepala sekolah dalam mempengaruhi, mendorong, membimbing, mengarahkan dan menggerakkan guru, staf, siswa, orang tua siswa dan pihak lain yang terkait untuk bekerja atau berperan serta guna mencapai tujuan yang telah ditetapkan ${ }^{44}$.

Usaha kepemimpinan untuk mengefektifkan sekolah, harus dilakukan dengan mempergunakan strategi yang paling tinggi jaminan kemampuannya untuk mencapai tujuan sekolah. Strategi seperti itu menuntut kemampuan kepala sekolah mengimplementasikan fungsifungsi kepemimpinan secara efektif dan efisien. Fungsifungsi kepemimpinan itu terdiri dari ${ }^{45} 1$ ), pimpinan sebagai penentu arah, 2), pimpinan sebagai wakil dan juru bicara organisasi, 3), pimpinan sebagai komunikator yang aktif, 4), pimpinan sebagai mediator, dan 5), sebagai integrator.

Kepala sekolah memiliki tanggung jawab untuk melaksanakan kebijakan nasional dalam mengupayakan pendidikan paling baik bagi anak-anak sekolah. Walaupun begitu, kepala sekolah bukanlah robot yang tidak berpikir, melainkan anggota komunitas pendidik. Komunitas tersebut harus berpartisipasi aktif mendiskusikan berbagai kebijakan sebelum hal itu ditentukan oleh Negara. Para kepala sekolah perlu terus menerus mengikuti perkembangan prakarsa kebijakan yang sedang dipertimbangkan oleh pemerintah ${ }^{46}$. Kepala sekolah juga agen komunitas lokal yang melayani orang tua yang mengirim putra-putrinya ke sekolah dan berusaha mewujudkan sekolah yang unggul.

Efektivitas kepemimpinan kepala sekolah merupakan perilaku manajerial di sebuah sekolah. Karena itu, peranan kepala ekolah sebagai pemimpin adalah proses kepemimpinan pendidikan yang tidak terlepas dari upaya menjalankan manajemen sekolah secara efektif. Hal itu dipengaruhi oleh pendekatan pengambilan keputusan pendidikan secara efektif. Kepala sekolah sebagai pimpinan lembaga pendidikan bertanggung jawab untuk memotivasi para guru, pegawai, dan siswa melakukan

\footnotetext{
${ }^{44}$ Depdiknas Dirjen Pendidikan Dasar dan Menengah, Rambu-rambu Penilaian Kinerja Institusi Pendidikan (SLTP dan SMU) (Jakarta: Rineka Cipta, 2000).

${ }^{45}$ Sondang P. Siagian, Filsafat Administrasi, (Jakarta: Gunung Agung, 1985)

${ }^{46}$ Wahyudin Nur Nasution.
} 
tindakan sesuai visi, misi, dan tujuan pendidikan. Kepemimpinan kepala sekolah juga harus bermuara kepada efektivitas kepemimpinan dalam pelaksanaan tugasnya. Kepala sekolah mempengaruhi dan memberi peluang bagi para guru dan staf personil untuk memimpin dirinya sendiri merupakan efektivitas kepemimpinan kepala sekolah yang paling optimal ${ }^{47}$.

\section{Kesimpulan}

Kepemimpinan adalah seorang yang mempunyai kemampuan, kekuatan seni untuk memengaruhi, memberikan aspirasi , dan mengarahkan perilaku seseorang atau kelompok/organisasi (memotivasi individu tanpa adanya unsur paksaan) di dalam kerjanya dengan cara kepatuhan, kepercayaan, kehormatan, dan kerja sama yang bersemangat dalam mencapai tujuan bersama. Kepemimpinan kepala sekolah adalah cara atau usaha kepala sekolah dalam mempengaruhi, mendorong, membimbing, mengarahkan dan menggerakkan guru, staf, siswa, orang tua siswa dan pihak lain yang terkait untuk bekerja atau berperan serta guna mencapai tujuan yang telah ditetapkan. Kepala sekolah harus menguasai konsep Kepemimpinan, konsep kepemimpinan Pendidikan, dan Konsep kepemimpinan kepala sekolah. Agar dapat mencapai tujuan pendidikan secara optimal, efektif, dan efisien, maka dibutuhkan kepemimpinan kepala sekolah yang bertanggungjawab dan memahami tugas pokok serta fungsinya. Fungsi kepemimpinan pendidikan; 1), educator ; 2), manajer; 3), administrator; 4), supervisor; 5), leader; (6) inovator; dan (7) motivator, disingkat EMASLIM.

\section{Daftar Referensi}

Depdiknas Dirjen Pendidikan Dasar dan Menengah, (2000), Rambu-rambu Penilaian Kinerja Institusi Pendidikan (SLTP dan SMU, Jakarta: Rineka Cipta.

Dirawat, dik, Pengantar Kepemimpinan Pendidikan. (Surabaya: Usaha Nasional 1986).

Jabnoun, N., Islam and Management, (Riyadh: International Islamic Publishing House 2008).

\footnotetext{
${ }^{47}$ Syafaruddin dan Asrul.
} 
Makawimbang, Jery H., Kepemimpinan Pendidikan yang Bermutu, (Bandung: Alfa Beta 2012).

Rivai, Veithzal, Kepemimpinan dan Perilaku Organisasi, (Jakarta: Rajawali Press, 2003).

Robbins, Stephen P, Organizational Behaviour, 9thedition, Englewood Cliff, (New Jersey: Prentice-Hall Inca, 2001).

Roe, W.H. T dan Drake, The Principalship, (New York: Macmilalan Publishing, 1980).

Rue, Leslie W. \& Byars, Lioyd L., Management: Skills and Application, (San Francisco: McGraw-Hill, 2000).

Rohmat, 'Kepemimpinan Pendidikan', Jurnal: Insania, 11 (1) (2006).

Overton, Rodney, Leadership Made Simple, (Singapura: Wharton Books, Pte. Ltd. 2002).

Owens, Robert G, Organizational Behavior in Education, (Boston: Allyn \& bacon Company, 1991).

Owens, Robert G., Organizational Behaviour in Education, (Boston: Allyn and Bacon, 1995).

Siagian, Sondang P., Filsafat Administrasi, (Jakarta: Gunung Agung, 1985).

Sutarto, Dasar-dasar Kepemimpinan Administrasi, (Yogyakarta: Gajah Mada University Press, 1991).

Syafaruddin dan Asrul, Kepemimpinan Pendidikan Kontemporer, (Bandung: Citapustaka Media, 2013).

Wahab, Abdul Aziz, Anatomi Organisasi dan Kepemimpinan Pendidikan, (Bandung: Alfabeta, 2008).

Wahjosumidjo, Kepemimpinan Kepala Sekolah: Tinjauan Teoretis dan Permasalahannya, (Jakarta: Raja Grafindo Persada, 2002).

Yulk. G., Leadership in Organizations, (New York: Pearson Prentice Hall, 2010). 